\title{
Analisis Kesalahan Mahasiswa dalam Menyelesaikan Soal Persamaan dan Pertidaksamaan pada Mata Kuliah Kalkulus I
}

\author{
Tuhfatul Janan ${ }^{1{ }^{*}}$, Anas Rangga Buana Hanafi ${ }^{2)}$ \\ ${ }^{12)}$ Sekolah Tinggi Agama Islam Muhammadiyah Probolinggo, Indonesia \\ ${ }^{1)}$ tuhfatuljanan4@gmail.com, ${ }^{2)}$ anas.rangga266@gmail.com
}

open

access

*Penulis Korespondensi

Histori Artikel:

Submit: 2022-01-17

Diterima: 2022-01-24

Dipublikasikan: 2022-02-01

Kata Kunci:

Analisis kesalahan; kalkulus; persamaan; pertidaksamaan

Jurnal Pendidikan Sains dan

Komputer is licensed under a

Creative Commons Attribution-

NonCommercial 4.0

International (CC BY-NC 4.0).

\begin{abstract}
ABSTRAK
Penelitian ini bertujuan untuk memberikan gambaran secara lebih rinci tentang berbagai kesalahan yang dilakukan oleh mahasiswa dalam menyelesaikan soal persamaan dan pertidaksamaan pada mata kuliah kalkulus I. Metode penelitian ini adalah metode deskriptif kualitatif. Sedangkan subjek dalam penelitian ini adalah mahasiswa Tadris Matematika STAI Muhammadiyah Probolinggo Semester I tahun akademik 2021/2022. Teknik pengumpulan data yang digunakan pada penelitian ini adalah ujian dan wawancara. Peneliti memeriksa keabsahan data hasil wawancara dengan menggunakan triangulasi waktu agar memperoleh data yang valid. Selanjutnya, peneliti melakukan analisis data yang sudah valid dan menarik suatu kesimpulan. Berdasarkan hasil penelitian, dapat disimpulkan bahwa subjek X melakukan 7 jenis kesalahan, yaitu kesalahan dalam menyamakan penyebut, memindahkan suatu bilangan dari ruas kiri ke ruas kanan, menentukan daerah penyelesaian pada garis bilangan, memahami definisi pertidaksamaan nilai mutlak, menuliskan tanda kurung, menentukan himpunan penyelesaian, dan menuliskan himpunan penyelesaian. Sedangkan subjek Y hanya melakukan 4 jenis kesalahan, yaitu kesalahan dalam menuliskan notasi matematika, memisahkan pembilang dan penyebut, menentukan himpunan penyelesaian, dan menuliskan himpunan penyelesaian.
\end{abstract}

\section{LATAR BELAKANG}

Matematika merupakan salah satu disiplin ilmu yang dipelajari pada setiap jenjang pendidikan, mulai dari pendidikan dasar sampai pendidikan tinggi (Fatimah \& Yerizon, 2019). Hal ini dikarenakan matematika memiliki peranan penting dalam kehidupan sehari-hari, diantaranya menghitung, mengukur, dan menganalisis. Dengan belajar matematika, peserta didik akan dilatih untuk berpikir secara rasional sehingga dapat menjadi pemecah masalah yang baik (Nopriani, 2017). Oleh karena itu, ilmu matematika perlu diberikan kepada semua peserta didik pada setiap jenjang pendidikan untuk membekali mereka dengan kemampuan berpikir logis, analitis, sistematis, kritis dan kreatif, serta kemampuan dalam bekerja sama (Depdiknas, 2006). Kemampuan-kemampuan tersebut harus dimiliki oleh peserta didik untuk menghadapi perkembangan teknologi yang semakin kompetitif.

Salah satu cabang ilmu matematika yang dapat mendukung tercapainya kemampuan tersebut adalah kalkulus. Kalkulus digunakan dalam berbagai disiplin ilmu dan dianggap sebagai mata kuliah yang penting bagi mahasiswa (Bergwall \& Hemmi, 2017; Ferrer, 2016). Kalkulus I merupakan salah satu mata kuliah wajib yang ditempuh oleh mahasiswa Tadris Matematika STAI Muhammadiyah Probolinggo Semester I tahun akademik 2021/2022 sebagai mata kuliah prasyarat untuk mata kuliah kalkulus II. Materi yang diajarkan pada kalkulus I diantaranya adalah materi tentang persamaan dan pertidaksamaan. 


\section{Jurnal Pendidikan Sains dan Komputer}

Berdasarkan data dari hasil Ujian Tengah Semester (UTS) tahun akademik 2021/2022 diperoleh bahwa beberapa mahasiswa pada mata kuliah kalkulus I Program Studi Tadris Matematika mendapatkan nilai yang kurang memuaskan. Hal itu dikarenakan beberapa mahasiswa melakukan kesalahan dalam mengerjakan soal UTS mata kuliah kalkulus I, yaitu pada materi persamaan dan pertidaksamaan. Materi ini sebenarnya telah diajarkan di jenjang sekolah, baik di sekolah menengah pertama maupun sekolah menengah atas. Akan tetapi, pada kenyataannya masih banyak mahasiswa yang melakukan kesalahan dalam menyelesaikan soal persamaan dan pertidaksamaan tersebut.

Menurut (Ardiawan, 2015), kesalahan adalah suatu bentuk penyimpangan terhadap jawaban yang sebenarnya yang bersifat sistematis. Kesalahan mahasiswa dalam menyelesaikan soal dapat dikategorikan menjadi kesalahan konsep, yaitu kesalahan dalam menyimpulkan suatu hal berdasarkan ciri yang diidentifikasi (Sumiati \& Asra, 2009). Sebagaimana dalam penelitian Rimo (2018) dan Ahmad (2019) ditemukan kesulitan yang dialami oleh mahasiswa dalam menyelesaikan soal volume benda putar yang dikarenakan kurangnya pemahaman konsep. Kesulitan tersebut mengakibatkan mahasiswa mengalami kesalahan dalam menjawab soal ujian. Kesalahan dalam menyelesaikan permasalahan dapat pula disebabkan oleh kesalahan menggunakan data, kesalahan interpretasi bahasa, kesalahan teknis, dan kesalahan penarikan kesimpulan (Fatimah, 2013).

Analisis kesalahan adalah suatu upaya untuk mengamati, menemukan, dan mengklasifikasi kesalahan dengan aturan tertentu (Astuty \& Wijayanti, 2013). Menurut (Siswandi \& Sujadi, 2016; Umam, 2014), kesalahan-kesalahan mahasiswa dalam menyelesaikan permasalahan matematika perlu dianalisis untuk mengetahui jenis dan letak kesalahannya. Hal ini bertujuan untuk memperbaiki kegiatan belajar dan mengajar serta meningkatkan prestasi belajar mahasiswa (Anugraheni, 2019; Farida, 2015). Oleh karena itu, analisis kesalahan tersebut dapat dijadikan acuan bagi dosen untuk melakukan evaluasi dan memberikan solusi yang tepat kepada mahasiswa agar kesalahan-kesalahan tersebut dapat segera diperbaki dan tidak terulang kembali.

Berdasarkan uraian tersebut, penulis tertarik untuk menganalisis kesalahan mahasiswa dalam menyelesaikan soal persamaan dan pertidaksamaan pada mata kuliah kalkulus I. Penelitian ini diharapkan dapat memberikan gambaran secara lebih rinci tentang berbagai kesalahan yang dilakukan oleh mahasiswa dalam menyelesaikan soal persamaan dan pertidaksamaan. Selain itu, dalam penelitian ini juga akan diidentifikasi penyebab mahasiswa melakukan berbagai kesalahan tersebut sehingga dosen dapat melakukan perbaikan melalui kegiatan pembelajaran.

\section{STUDI LITERATUR}

Hasil penelitian dari Zukhrufurrohmah \& Kusumawardana (2019) tentang analisis kesalahan matematis mahasiswa teknik sipil pada mata kuliah kalkulus II menunjukkan bahwa kesalahan yang dominan dilakukan oleh mahasiswa adalah kesalahan memanipulasi aljabar. Kesalahan terbesar kedua adalah kesalahan melakukan perhitungan atau komputasi. Akan tetapi, kesalahan memilih rumus atau teorema jarang dilakukan oleh mahasiswa, meskipun pemilihan rumus atau teorema yang tepat tidak menjamin mahasiswa benar dalam mengaplikasikannya. Selain itu, penelitian dari Rahmawati (2017) menunjukkan bahwa beberapa kesalahan yang dilakukan oleh mahasiswa dalam menyelesaikan soal pertidaksamaan pada mata kuliah kalkulus I adalah kesalahan dalam melakukan proses perhitungan, menentukan himpunan penyelesaian, dan kesalahan dalam menentukan nilai pembuat nol pada garis 
Jurnal Pendidikan Sains dan Komputer

Volume 2, Number 1, February 2022

e-ISSN: $2809-476 \mathrm{X}$

bilangan. Berdasarkan hasil penelitian di atas, maka dibutuhkan penelitian lebih lanjut untuk menyelesaikan secara tuntas permasalahan tersebut.

\section{METODE}

Metode penelitian yang digunakan adalah metode deskriptif kualitatif. Penelitian ini akan mengkaji data kualitatif yang kemudian akan dideskripsikan untuk mendapatkan gambaran secara rinci dan mendalam mengenai beberapa kesalahan mahasiswa dalam menyelesaikan soal persamaan dan pertidaksamaan pada mata kuliah Kalkulus I. Subjek dalam penelitian ini adalah mahasiswa Tadris Matematika STAI Muhammadiyah Probolinggo Semester I tahun akademik 2021/2022. Kriteria yang digunakan dalam penelitian ini adalah hasil jawaban mahasiswa mewakili kesalahan yang sering dilakukan oleh mahasiswa pada umumnya, hasil jawaban tersebut masih bersesuaian dengan soal ujian, dan struktur kalimat serta bahasanya masih baik. Instrumen utama dalam penelitian ini adalah peneliti, karena peneliti sebagai penentu dalam mengumpulkan, menganalisis dan menyajikan data. Sedangkan instrumen bantu dalam penelitian ini adalah soal ujian persamaan dan pertidaksamaan serta pedoman wawancara.

Teknik pengumpulan data yang digunakan pada penelitian ini adalah ujian dan wawancara. Ujian yang digunakan adalah Ujian Tengah Semester (UTS) tahun akademik 2021/2022 berupa soal uraian tentang materi persamaan dan pertidaksamaan. UTS ini diberikan kepada subjek setelah menerima materi tentang persamaan dan pertidaksamaan pada perkuliahan Kalkulus I. Wawancara pada penelitian ini adalah dengan mewawancarai subjek berdasarkan hasil jawabannya terhadap soal UTS yang diberikan. Wawancara ini bertujuan untuk mengklarifikasi jawaban tertulis dari subjek dan memperoleh informasi penyebab subjek melakukan beberapa kesalahan dalam menjawab soal UTS Kalkulus I. Menurut (Sugiyono, 2016), pedoman wawancara bersifat tidak terstruktur karena peneliti tidak menggunakan pedoman wawancara yang telah tersusun secara sistematis dan lengkap untuk mengumpulkan data, tetapi pedoman wawancara yang digunakan hanya berupa garis-garis besar permasalahan yang akan ditanyakan. Tidak semua subjek mendapatkan pertanyaan yang sama dari peneliti, tergantung dari banyaknya informasi yang dibutuhkan oleh peneliti. Setelah melakukan wawancara, peneliti memeriksa keabsahan data hasil wawancara dengan menggunakan triangulasi waktu agar memperoleh data yang valid. Selanjutnya, peneliti melakukan analisis data yang sudah valid dan menarik suatu kesimpulan.

\section{HASIL DAN PEMBAHASAN}

Mahasiswa diberikan soal uraian tentang materi persamaan dan pertidaksamaan pada saat UTS selama 100 menit. Selama mengerjakan soal tersebut, mahasiswa dilarang membuka buku catatan dan bertanya kepada mahasiswa yang lain. Soal yang diberikan kepada mahasiswa adalah tentukan himpunan penyelesaian dari persamaan dan pertidaksamaan berikut ini :
a. $\frac{x+1}{-x+1}+\frac{x-2}{x+1}=-1$
b. $2|x-3|=3 x+1$
c. $\frac{x^{2}-7 x-18}{x^{2}-10 x+24}<0$ 
d. $|2 x+1| \geq 4 x-5$

Setelah semua mahasiswa mengerjakan soal tersebut, selanjutnya peneliti mengidentifikasi jawaban dari mahasiswa tersebut untuk memperoleh subjek penelitian. Berdasarkan kriteria yang telah disebutkan di atas, terdapat dua mahasiswa yang memenuhi kriteria sebagai subjek penelitian. Kedua mahasiswa tersebut disimbolkan sebagai subjek X dan subjek Y. Kemudian, peneliti mewawancarai kedua subjek terkait jawaban tertulisnya. Pada waktu yang berbeda, peneliti memberikan soal mengenai persamaan dan pertidaksamaan lagi kepada kedua subjek lalu mewawancarai mereka sesuai dengan jawaban tertulisnya. Setelah itu, peneliti membandingkan kesesuaian antara data yang diperoleh dari tes pertama dengan data yang diperoleh dari tes kedua. Jika data yang diperoleh telah sesuai maka data pada tes pertama sudah valid. Hal ini menjadi acuan bagi peneliti untuk segera melakukan analisis dari data tersebut.

Berdasarkan hasil jawaban tertulis dan wawancara yang diperoleh dari kedua subjek berkaitan dengan jawaban tertulisnya, akan disajikan hasil analisis dari subjek penelitian sebagai berikut:

1. Subjek X

Berikut adalah hasil jawaban tertulis soal nomor 1 oleh subjek $\mathrm{X}$ :

$\frac{x+1}{-x+1}+\frac{x-2}{x+1}=-1$
$=(x+1)^{2}+(-x+1)(x-2)=-1$
$\left(x^{2}+2 x+1\right)+\left(-x^{2}+3 x-2\right)=-1$
$x^{2}+2+1-x^{2}+3 x-2+1=0$
$5 x=0$
$x=0$

Gambar 1. Jawaban Soal Nomor 1 oleh Subjek X

Berdasarkan hasil jawaban tertulis dan wawancara terkait jawaban tertulis soal nomor 1, beberapa kesalahan yang dilakukan oleh subjek X adalah

1. Kesalahan dalam menyamakan penyebut. Subjek $\mathrm{X}$ mengalikan pembilang $x+1$ dengan penyebut $x+1$ dan mengalikan pembilang $x-2$ dengan penyebut $-x+1$ seperti terlihat pada langkah kedua. Akan tetapi, subjek $X$ tidak mengalikan penyebut $-x+1$ dengan penyebut $x+1$. Seharusnya, subjek $\mathrm{X}$ mengalikan penyebut $-x+1$ dengan $x+1$ agar ruas sebelah kiri tidak berubah nilai. Berdasarkan hasil wawancara, subjek X melakukan kesalahan tersebut karena belum memahami cara yang tepat untuk menyamakan penyebut.

2. Kesalahan dalam menentukan himpunan penyelesaian. Hal ini terjadi karena subjek $X$ melakukan kesalahan nomor 1 .

Berikut adalah hasil jawaban tertulis soal nomor 2 oleh subjek X : 


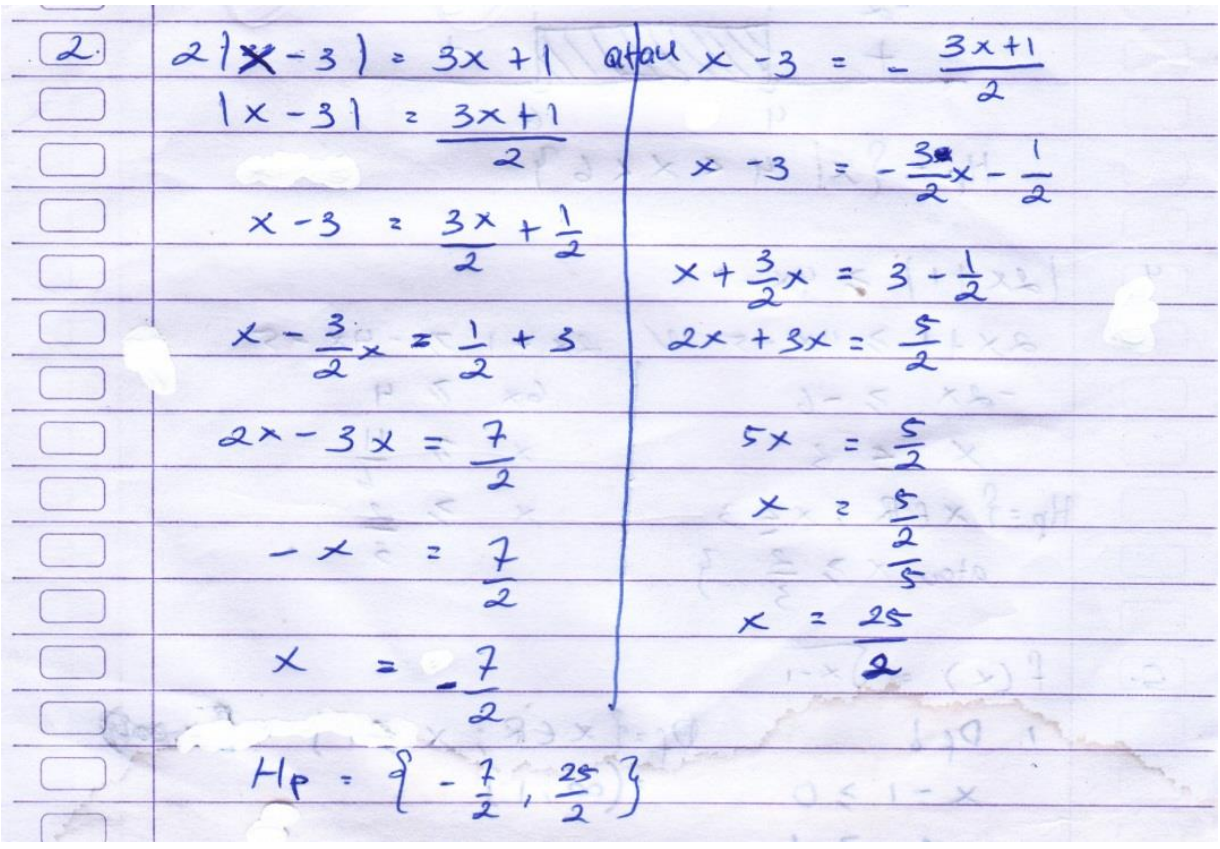

Gambar 2. Jawaban Soal Nomor 2 oleh Subjek X

Berdasarkan hasil jawaban tertulis dan wawancara terkait jawaban tertulis soal nomor 2, beberapa kesalahan yang dilakukan oleh subjek X adalah

1. Kesalahan dalam menyamakan penyebut. Hal ini terlihat pada langkah kelima dari jawaban sebelah kiri di ruas kiri. Subjek X menuliskan jawaban $2 x-3 x$, padahal pada langkah sebelumnya diperoleh jawaban $x-\frac{3}{2} x$. Seharusnya, subjek $\mathrm{X}$ menuliskan jawaban $\frac{2 x-3 x}{2}$ karena $x$ harus dikalikan dengan $\frac{2}{2}$ agar nilainya sama dengan $x-\frac{3}{2} x$. Selain itu, kesalahan ini juga terlihat pada langkah keempat dari jawaban sebelah kanan di ruas kiri. Subjek $\mathrm{X}$ menuliskan jawaban $2 x+3 x$, padahal pada langkah sebelumnya diperoleh jawaban $x+\frac{3}{2} x$. Seharusnya, subjek $\mathrm{X}$ menuliskan jawaban $\frac{2 x+3 x}{2}$ karena $x$ harus dikalikan dengan $\frac{2}{2}$ agar nilainya sama dengan $x+\frac{3}{2} x$. Berdasarkan hasil wawancara, subjek X melakukan kesalahan tersebut karena belum memahami cara yang tepat untuk menyamakan penyebut.

2. Kesalahan dalam memindahkan suatu bilangan dari ruas kiri ke ruas kanan. Hal ini terlihat pada langkah keenam dari jawaban sebelah kanan. Subjek X menuliskan jawaban $x=\frac{\frac{5}{2}}{5}$, padahal pada langkah sebelumnya diperoleh jawaban $5 x=\frac{5}{2}$. Seharusnya, subjek $\mathrm{X}$ menuliskan jawaban $x=\left(\frac{5}{2}\right) \cdot\left(\frac{1}{5}\right)$ karena kedua ruas harus dikalikan dengan $\frac{1}{5}$ dengan tujuan untuk mengubah $5 x$ menjadi $x$ pada ruas kiri. Akibatnya, diperoleh jawaban $x=\frac{1}{2}$. Berdasarkan hasil wawancara, subjek X melakukan kesalahan tersebut karena mengalami kebingungan ketika memindahkan suatu bilangan dari suatu ruas ke ruas lain yang berkaitan dengan bilangan pecahan. Perlu dicatat bahwa jawaban dari subjek X sebelumnya yaitu $5 x=\frac{5}{2}$ 
bernilai salah. Hal ini terjadi karena subjek X melakukan kesalahan nomor 1 .

3. Kesalahan dalam menentukan himpunan penyelesaian. Hal ini terjadi karena subjek $X$ melakukan kesalahan nomor 1 dan 2.

Berikut adalah hasil jawaban tertulis soal nomor 3 oleh subjek X :

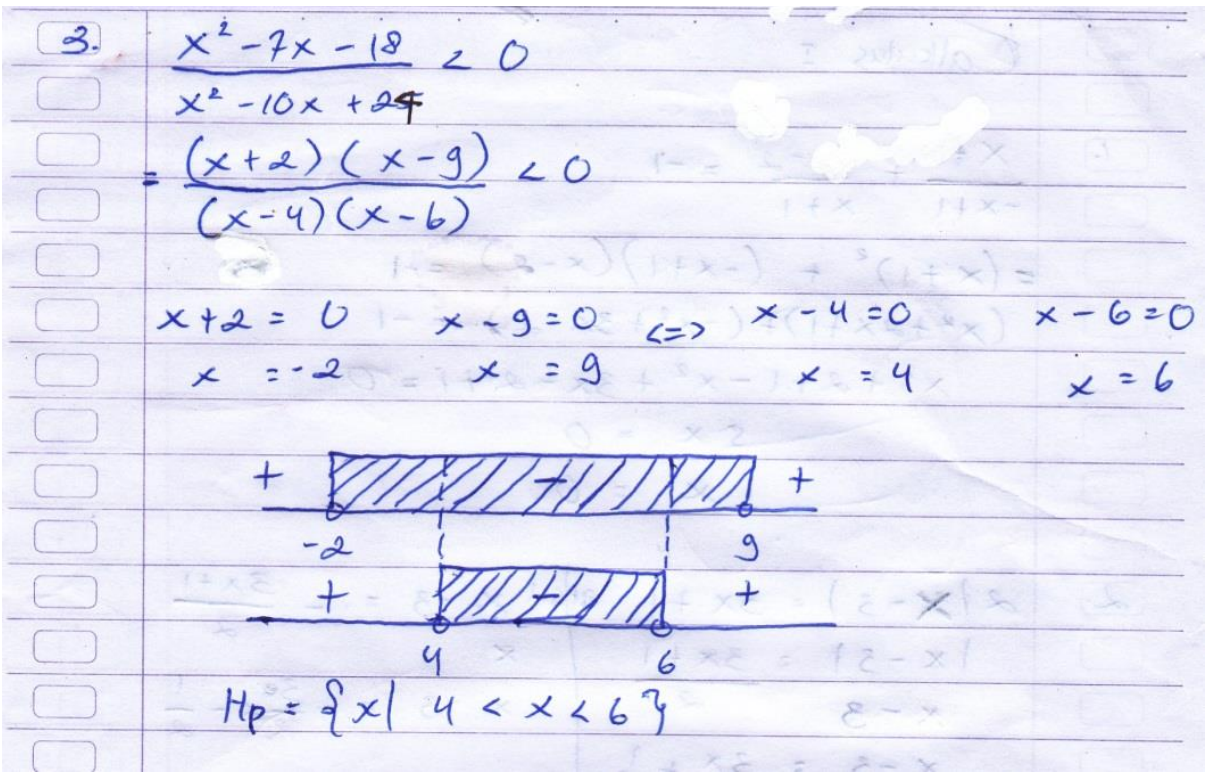

Gambar 3. Jawaban Soal Nomor 3 oleh Subjek X

Berdasarkan hasil jawaban tertulis dan wawancara terkait jawaban tertulis soal nomor 3, beberapa kesalahan yang dilakukan oleh subjek $\mathrm{X}$ adalah

1. Kesalahan dalam menentukan daerah penyelesaian pada garis bilangan. Subjek X menuliskan dua garis bilangan masing-masing untuk pembilang dan penyebut. Akan tetapi, subjek $\mathrm{X}$ menarik kesimpulan dengan mengambil irisan dari kedua garis bilangan yang memiliki daerah penyelesaian bernilai negatif seperti yang terlihat pada gambar. Seharusnya, subjek X menarik kesimpulan dengan mengambil irisan dari kedua garis bilangan yang daerah penyelesaiannya berbeda tanda, yaitu daerah penyelesaian yang bernilai positif pada suatu garis bilangan dan daerah penyelesaian yang bernilai negatif pada garis bilangan yang lain. Hal ini dikarenakan pertidaksamaan yang ada pada soal adalah kurang dari nol sehingga jika pembilang bernilai positif maka penyebutnya bernilai negatif dan begitu sebaliknya. Berdasarkan hasil wawancara, subjek X melakukan kesalahan tersebut karena mengalami kebingungan ketika menentukan daerah penyelesaian pada garis bilangan.

2. Kesalahan dalam menentukan himpunan penyelesaian. Hal ini terjadi karena subjek $\mathrm{X}$ melakukan kesalahan nomor 1. Seharusnya, diperoleh jawaban akhir $2<x<4$ atau $6<x<$ 9.

3. Kesalahan dalam menuliskan himpunan penyelesaian. Subjek X kurang menuliskan notasi $\mathbb{R}$, yaitu himpunan semua bilangan riil seperti yang terlihat pada langkah terakhir.

Berikut adalah hasil jawaban tertulis soal nomor 4 oleh subjek X : 


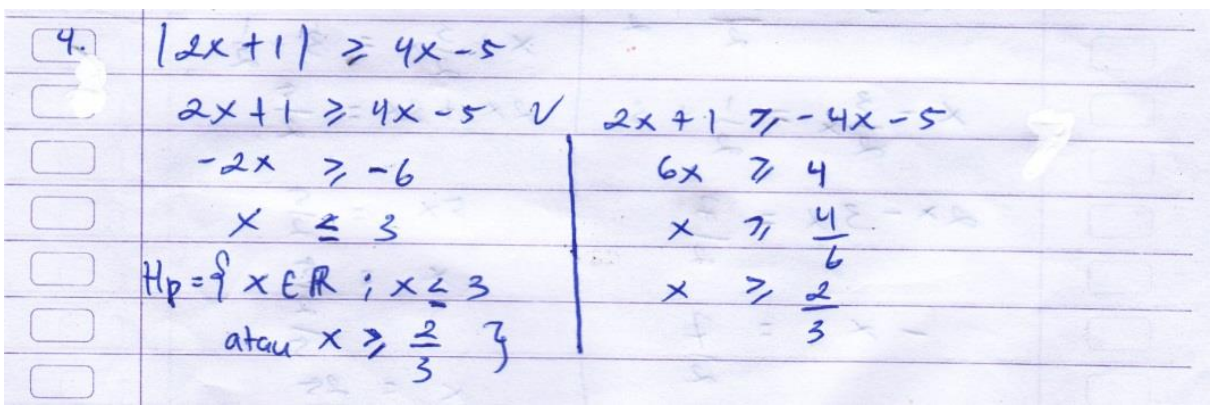

Gambar 4. Jawaban Soal Nomor 4 oleh Subjek X

Berdasarkan hasil jawaban tertulis dan wawancara terkait jawaban tertulis soal nomor 4 , beberapa kesalahan yang dilakukan oleh subjek X adalah

1. Kesalahan dalam memahami definisi pertidaksamaan nilai mutlak. Subjek X menuliskan $2 x+$ $1 \geq-4 x-5$ pada langkah pertama dari jawaban sebelah kanan. Seharusnya, subjek $\mathrm{X}$ menuliskan $2 x+1 \leq-(4 x-5)$ karena pada jawaban sebelah kiri subjek $\mathrm{X}$ telah menuliskan $2 x+1 \geq 4 x-5$ sesuai dengan definisi pertidaksamaan nilai mutlak. Berdasarkan hasil wawancara, subjek X melakukan kesalahan tersebut karena mengalami ketidaktelitian ketika menuliskan notasi " $\leq$ ".

2. Kesalahan dalam menuliskan tanda kurung. Subjek $X$ menuliskan $-4 x-5$ pada langkah pertama dari jawaban sebelah kanan di ruas kanan. Seharusnya, subjek X menuliskan $-(4 x-$ 5). Hal ini sesuai dengan jawaban subjek $X$ pada langkah selanjutnya yaitu $6 x \geq 4$. Berdasarkan hasil wawancara, subjek $\mathrm{X}$ melakukan kesalahan tersebut karena mengalami ketidaktelitian ketika menuliskan tanda kurung. Perlu dicatat bahwa jawaban dari subjek $\mathrm{X}$ yaitu $6 x \geq 4$ bernilai salah. Hal ini terjadi karena subjek $\mathrm{X}$ melakukan kesalahan nomor 1 .

3. Kesalahan dalam menentukan himpunan penyelesaian. Hal ini terjadi karena subjek $X$ melakukan kesalahan nomor 1 dan 2.

Berdasarkan hasil dari analisis di atas, beberapa kesalahan yang dilakukan oleh subjek X disajikan seperti pada tabel berikut :

Tabel 1. Deskripsi Kesalahan dari Subjek X

\begin{tabular}{cl}
\hline No. & \multicolumn{1}{c}{ Deskripsi Kesalahan } \\
\hline 1. & Kesalahan dalam menyamakan penyebut \\
\hline 2. & Kesalahan dalam memindahkan suatu bilangan dari ruas kiri ke ruas kanan \\
\hline 3. & Kesalahan dalam menentukan daerah penyelesaian pada garis bilangan \\
\hline 4. & Kesalahan dalam memahami definisi pertidaksamaan nilai mutlak \\
\hline 5. & Kesalahan dalam menuliskan tanda kurung \\
\hline 6. & Kesalahan dalam menentukan himpunan penyelesaian \\
\hline 7. & Kesalahan dalam menuliskan himpunan penyelesaian \\
\hline
\end{tabular}

2. Subjek Y 
Berikut adalah hasil jawaban tertulis soal nomor 1 oleh subjek Y :

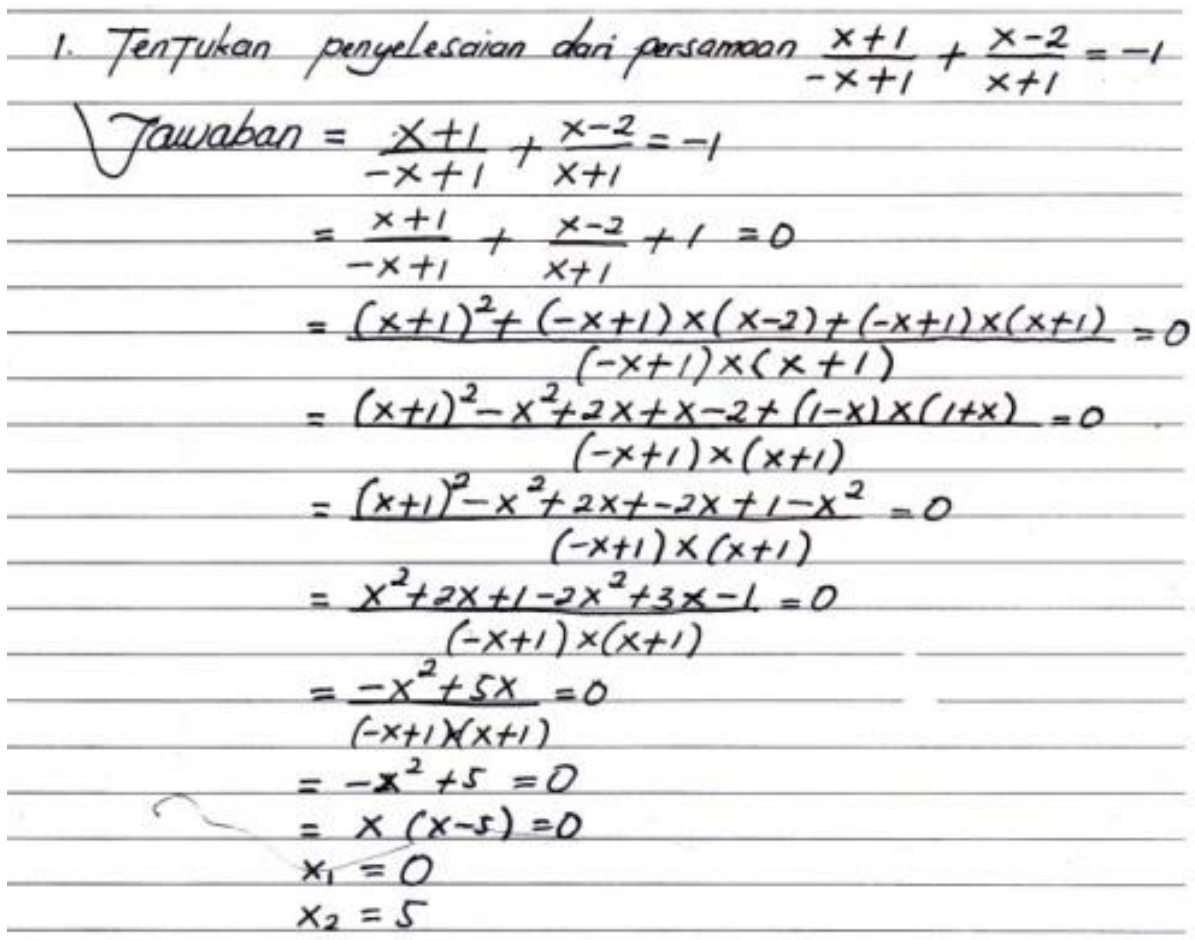

Gambar 5. Jawaban Soal Nomor 1 oleh Subjek Y

Berdasarkan hasil jawaban tertulis dan wawancara terkait jawaban tertulis soal nomor 1, beberapa kesalahan yang dilakukan oleh subjek Y adalah

1. Kesalahan dalam menuliskan notasi matematika. Subjek Y menuliskan notasi " = " di sebelah kiri pada setiap langkah perhitungan. Hal ini akan mengakibatkan kebingungan bagi setiap pembaca. Seharusnya, subjek Y tidak perlu menuliskan notasi tersebut, karena subjek Y juga menuliskan notasi " = " di sebelah kanan pada setiap langkah perhitungan. Berdasarkan hasil wawancara, subjek Y melakukan kesalahan tersebut karena belum memahami cara yang tepat untuk menuliskan notasi " = ".

2. Kesalahan dalam menuliskan himpunan penyelesaian. Subjek hanya menuliskan jawaban akhir $x_{1}=0$ kemudian pada baris selanjutnya menuliskan $x_{2}=5$. Seharusnya, subjek $\mathrm{Y}$ menuliskan jawaban akhir dengan menggunakan kata penghubung "atau", yaitu $x_{1}=0$ atau $x_{2}=5$. Berdasarkan hasil wawancara, subjek Y melakukan kesalahan tersebut karena belum memahami cara yang tepat untuk menuliskan kata penghubung "atau".

Berikut adalah hasil jawaban tertulis soal nomor 2 oleh subjek Y : 


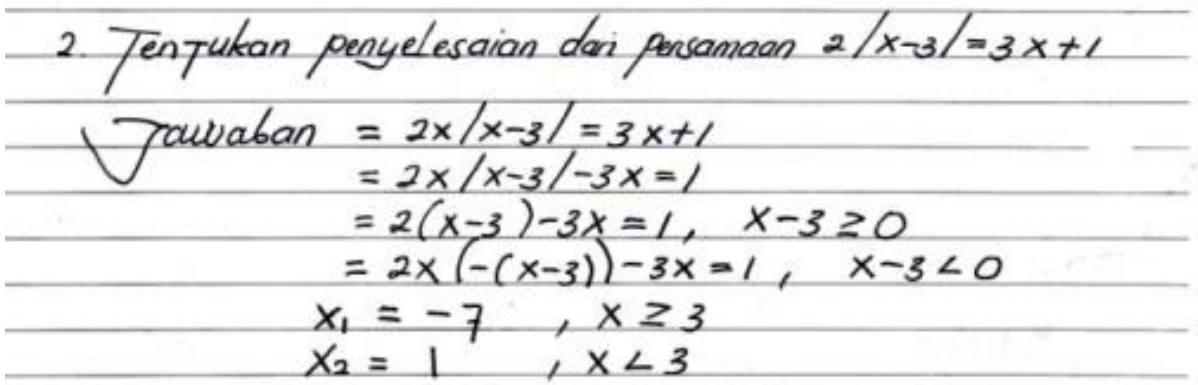

Gambar 6. Jawaban Soal Nomor 2 oleh Subjek Y

Berdasarkan hasil jawaban tertulis dan wawancara terkait jawaban tertulis soal nomor 2, beberapa kesalahan yang dilakukan oleh subjek Y adalah

1. Kesalahan dalam menuliskan notasi matematika. Subjek Y menuliskan notasi " = " di sebelah kiri pada setiap langkah perhitungan. Hal ini merupakan kesalahan yang sama yang dilakukan oleh subjek Y seperti pada soal nomor 1 di atas. Selain itu, subjek Y juga menuliskan notasi perkalian dengan " $x$ ", notasi yang sama dengan variabel " $x$ " seperti yang terlihat pada langkah pertama, kedua, dan keempat. Hal ini akan mengakibatkan kebingungan bagi setiap pembaca karena adanya kesamaan notasi. Seharusnya, subjek Y menuliskan notasi perkalian cukup dengan ".". Berdasarkan hasil wawancara, subjek Y melakukan kesalahan tersebut karena mengalami ketidaktelitian ketika menuliskan notasi " $x$ ".

2 Kesalahan dalam menentukan himpunan penyelesaian. Subjek Y menuliskan jawaban akhir $x_{1}=-7, x \geq 3$ kemudian pada baris selanjutnya menuliskan $x_{2}=1, x<3$. Seharusnya, subjek Y menarik kesimpulan bahwa jawaban $x_{1}=-7, x \geq 3$ bernilai salah karena keduanya saling berlawanan. Akibatnya, jawaban yang benar adalah $x=1$. Berdasarkan hasil wawancara, subjek Y melakukan kesalahan tersebut karena mengalami kebingungan ketika menarik kesimpulan dari kedua jawaban tersebut.

Berikut adalah hasil jawaban tertulis soal nomor 3 oleh subjek Y :

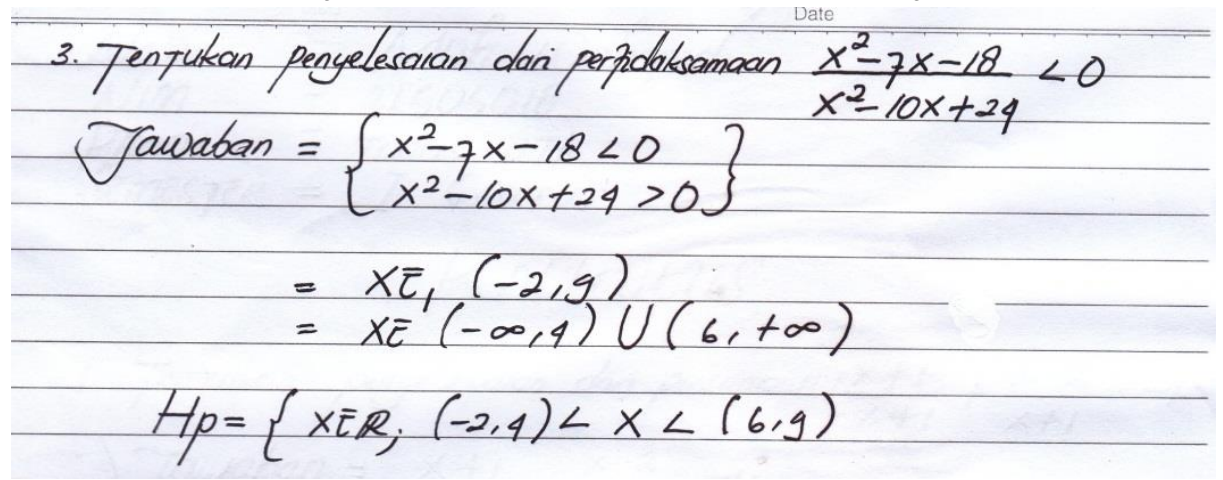

Gambar 7. Jawaban Soal Nomor 3 oleh Subjek Y

Berdasarkan hasil jawaban tertulis dan wawancara terkait jawaban tertulis soal nomor 3, beberapa kesalahan yang dilakukan oleh subjek Y adalah

1. Kesalahan dalam menuliskan notasi matematika. Subjek Y kembali menuliskan notasi " = " di sebelah kiri pada setiap langkah perhitungan. Hal ini merupakan kesalahan yang sama yang 
dilakukan oleh subjek Y seperti pada soal nomor 1 dan 2 di atas. Selain itu, subjek Y juga menuliskan notasi "\{\}" seperti yang terlihat pada langkah pertama. Seharusnya, subjek Y tidak perlu menuliskan notasi tersebut. Berdasarkan hasil wawancara, subjek Y melakukan kesalahan tersebut karena belum memahami cara yang tepat untuk menuliskan notasi " \{\}$"$.

2 Kesalahan dalam memisahkan pembilang dan penyebut. Pada langkah pertama, subjek Y menuliskan pembilang $x^{2}-7 x-18<0$ dan penyebut $x^{2}-10 x+24>0$. Seharusnya, subjek Y perlu menuliskan situasi lain yaitu pembilang $x^{2}-7 x-18>0$ dan penyebut $x^{2}-$ $10 x+24<0$. Hal ini dikarenakan bilangan pecahan gabungan dari pembilang dan penyebut tersebut kurang dari nol. Berdasarkan hasil wawancara, subjek Y melakukan kesalahan tersebut karena mengalami ketidaktelitian ketika memisahkan pembilang dan penyebut.

3. Kesalahan dalam menuliskan himpunan penyelesaian. Subjek Y menuliskan jawaban akhir dengan $(-2,4)<x<(6,9)$. Seharusnya, subjek Y menuliskan jawaban akhir dengan $-2<$ $x<4$ atau $6<x<9$. Berdasarkan hasil wawancara, subjek $\mathrm{Y}$ melakukan kesalahan tersebut karena mengalami kebingungan ketika menuliskan himpunan penyelesaian dengan menggunakan notasi interval. Selain itu, subjek Y seharusnya juga menuliskan notasi "\}" pada akhir himpunan penyelesaian. Berdasarkan hasil wawancara, subjek $\mathrm{Y}$ melakukan kesalahan tersebut karena mengalami ketidaktelitian ketika menuliskan notasi " \} ".

Berikut adalah hasil jawaban tertulis soal nomor 4 oleh subjek Y :

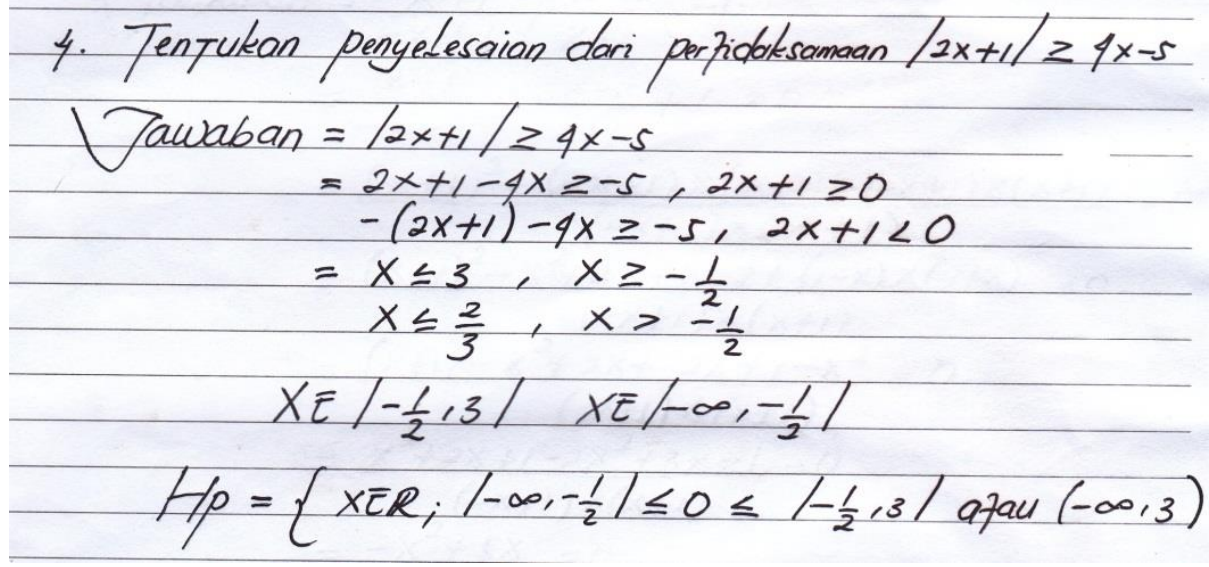

Gambar 8. Jawaban Soal Nomor 4 oleh Subjek Y

Berdasarkan hasil jawaban tertulis dan wawancara terkait jawaban tertulis soal nomor 4 , beberapa kesalahan yang dilakukan oleh subjek $\mathrm{Y}$ adalah

1. Kesalahan dalam menuliskan notasi matematika. Subjek Y kembali menuliskan notasi " = " di sebelah kiri pada setiap langkah perhitungan. Hal ini merupakan kesalahan yang sama yang dilakukan oleh subjek Y seperti pada soal nomor 1, 2, dan 3 di atas. Selain itu, subjek Y juga menuliskan $x>-\frac{1}{2}$ seperti yang terlihat pada langkah kelima. Seharusnya, subjek $\mathrm{Y}$ menuliskan $x<-\frac{1}{2}$ karena pada langkah ketiga diperoleh $2 x+1<0$. Berdasarkan hasil wawancara, subjek Y melakukan kesalahan tersebut karena mengalami ketidaktelitian ketika menuliskan notasi " <". Selain itu, subjek Y juga menuliskan jawaban $x \in\left|-\frac{1}{2}, 3\right|$ kemudian 
di sebelah kanannya menuliskan $x \in\left|-\infty,-\frac{1}{2}\right|$ seperti yang terlihat pada langkah keenam. Seharusnya, subjek Y menambahkan kata penghubung "atau" dan mengubah notasi nilai mutlak dengan notasi interval yang benar. Akibatnya, jawaban yang benar adalah $x \in\left[-\frac{1}{2}, 3\right.$ ] atau $x \in\left(-\infty,-\frac{1}{2}\right)$. Berdasarkan hasil wawancara, subjek Y melakukan kesalahan tersebut karena belum memahami cara yang tepat untuk menuliskan kata penghubung "atau" dan mengalami kebingungan ketika menuliskan notasi interval.

2. Kesalahan dalam menuliskan himpunan penyelesaian. Subjek Y menuliskan $\operatorname{Hp}=\{x \in \mathbb{R} ; \mid$ $-\infty,-\frac{1}{2}|\leq 0 \leq|-\frac{1}{2}, 3 \mid$ atau $(-\infty, 3)$. Seharusnya, subjek Y cukup dengan menuliskan himpunan penyelesaian $=(-\infty, 3)$. Berdasarkan hasil wawancara, subjek Y melakukan kesalahan tersebut karena mengalami kebingungan ketika menuliskan himpunan penyelesaian dengan menggunakan notasi interval.

Berdasarkan hasil dari analisis di atas, beberapa kesalahan yang dilakukan oleh subjek Y disajikan seperti pada tabel berikut :

Tabel 2. Deskripsi Kesalahan dari Subjek Y

\begin{tabular}{cl}
\hline No. & \multicolumn{1}{c}{ Deskripsi Kesalahan } \\
\hline 1. & Kesalahan dalam menuliskan notasi matematika \\
\hline 2. & Kesalahan dalam memisahkan pembilang dan penyebut \\
\hline 3. & Kesalahan dalam menentukan himpunan penyelesaian \\
\hline 4. & Kesalahan dalam menuliskan himpunan penyelesaian \\
\hline
\end{tabular}

Berdasarkan deskripsi kesalahan pada tabel 1 dan tabel 2 di atas, subjek X melakukan 7 jenis kesalahan sedangkan subjek Y hanya melakukan 4 jenis kesalahan. Berdasarkan hasil wawancara, dapat diperoleh kesimpulan bahwa subjek X melakukan beberapa kesalahan tersebut dikarenakan belum memahami cara yang tepat untuk menyamakan penyebut, mengalami kebingungan ketika memindahkan suatu bilangan dari suatu ruas ke ruas lain yang berkaitan dengan bilangan pecahan dan menentukan daerah penyelesaian pada garis bilangan, serta mengalami ketidaktelitian ketika menuliskan notasi " $\leq$ " dan tanda kurung. Sedangkan subjek Y melakukan beberapa kesalahan tersebut dikarenakan belum memahami cara yang tepat untuk menuliskan notasi " = ", "\{\}", dan kata penghubung "atau", mengalami ketidaktelitian ketika menuliskan notasi " $x$ ", " $\}$ ", " <", dan memisahkan pembilang dan penyebut, serta mengalami kebingungan ketika menuliskan notasi interval, menuliskan himpunan penyelesaian dengan menggunakan notasi interval, dan menarik kesimpulan dari dua jawaban yang telah diperoleh.

\section{KESIMPULAN}

Berdasarkan hasil penelitian, dapat disimpulkan bahwa subjek X melakukan 7 jenis kesalahan, yaitu kesalahan dalam menyamakan penyebut, memindahkan suatu bilangan dari ruas kiri ke ruas kanan, menentukan daerah penyelesaian pada garis bilangan, memahami definisi pertidaksamaan nilai mutlak, menuliskan tanda kurung, menentukan himpunan penyelesaian, dan menuliskan himpunan penyelesaian. Sedangkan subjek Y hanya melakukan 4 jenis kesalahan, yaitu kesalahan dalam 


\section{Jurnal Pendidikan Sains dan Komputer}

menuliskan notasi matematika, memisahkan pembilang dan penyebut, menentukan himpunan penyelesaian, dan menuliskan himpunan penyelesaian.

\section{REFERENSI}

Ahmad, M. A. (2019). Analisis Kesulitan Belajar Matematika pada Materi Integral Luas Daerah di Bawah Kurva dan Volume Benda Putar. An-Nahdhah, 12(23), 159-176.

Anugraheni, I. (2019). Pengaruh Pembelajaran Problem Solving Model Polya terhadap Kemampuan Memecahkan Masalah Matematika Mahasiswa. Jurnal Pendidikan (Teori dan Praktik), 4(1), 1.

Ardiawan, Y. (2015). Analisis Kesalahan Mahasiswa dalam Menyelesaikan Soal Induksi Matematika di IKIP PGRI Pontianak. Jurnal Pendidikan Informatika Dan Sains, 4(1), 147-163.

Astuty, K. Y., \& Wijayanti, P. (2013). Analisis Kesalahan Siswa Kelas V dalam Menyelesaikan Soal Matematika Pada Materi Pecahan di SDN Medokan Semampir I/259 Surabaya. MATHEdunesa, $3(2), 1-7$.

Bergwall, A., \& Hemmi, K. (2017). The State of Proof in Finnish and Swedish Mathematics Textbooks-Capturing Differences in Approaches to Upper-Secondary Integral Calculus. Mathematical Thinking and Learning, 19(1), 1-18.

Depdiknas. (2006). Permendiknas No. 22 Tahun 2006 Tentang Standar Isi. Jakarta: Depdiknas, (Online), (https://goo.gl/btMZ9j) diakses 5 Januari 2022.

Farida, N. (2015). Analisis Kesalahan Siswa SMP Kelas VIII dalam Menyelesaikan Masalah Soal Cerita Matematika. AKSIOMA: Jurnal Program Studi Pendidikan Matematika, 4(2), 42-52.

Fatimah, F. (2013). Deskripsi Kesalahan Mahasiswa dalam Membuktikan Suatu Group (Studi pada Mahasiswa Pendidikan Matematika Universitas Al Asyariah Mandar). Jurnal Pepatuzdu, 5(1), 38-47.

Fatimah, S., \& Yerizon. (2019). Analysis of Difficulty Learning Calculus Subject for Mathematical Education Students. International Journal of Scientific and Technology Research, 8(03), 80-84.

Ferrer, F. P. (2016). Investigating Students'learning Difficulties in Integral Calculus. PEOPLE: International Journal of Social Sciences, 2(1), 310-324.

Nopriani, L, J., Panjaitan, A., Surya, E., \& Syahputra, E. (2017). Analysis Mathematical Problem Solving Skills of Student of the Grade VIII-2 Junior High School Bilah Hulu Labuhan Batu. International Journal of Novel Research in Education and Learning, 4(2), 131-137.

Rahmawati, A., (2017). Analisis Kesalahan Mahasiswa Pendidikan Matematika dalam Menyelesaikan Soal Pertidaksamaan pada Mata Kuliah Kalkulus I. Al-Jabar: Jurnal Pendidikan Matematika, $8(1), 81-90$.

Rimo, I. H. E. (2018). Analisis Kesulitan Mahasiswa Pendidikan Fisika FKIP-UNDANA dalam Memahami Materi Volume Benda Putar. Jurnal Ilmiah Soulmat: Jurnal Edukasi Pendidikan Matematika, 6(2), 91-104.

Siswandi, E., \& Sujadi, I. (2016). Analisis Kesalahan Siswa dalam Menyelesaikan Masalah Matematika Kontekstual pada Materi Segiempat Berdasarkan Analisis Newman Ditinjau dari Perbedaan Gender (Studi Kasus pada Siswa Kelas VII SMPN 20 Surakarta). Jurnal Elektronik Pembelajaran Matematika, 4(7), 633-643.

Sugiyono. (2016). Metode Penelitian Pendidikan (Pendekatan Kuantitatif, Kualitatif, dan R\&D). Bandung: Alfabeta. 
Jurnal Pendidikan Sains dan Komputer

Volume 2, Number 1, February 2022 e-ISSN: 2809-476X

Sumiati \& Asra. (2009). Metode Pembelajaran. Bandung: CV Wacana Prima.

Umam, M. D. (2014). Analisis Kesalahan Siswa dalam Menyelesaikan Soal Cerita Matematika Materi Operasi Hitung Pecahan. MATHEdunesa, 3(3), 131-134.

Zukhrufurrohmah, Z. \& Kusumawardana, A. S. (2019). Analisis Kesalahan Matematis Mahasiswa Teknik Sipil pada Mata Kuliah Kalkulus II. JRPM (Jurnal Review Pembelajaran Matematika), 4(1), 1-10. 